\title{
sciendo
}

\section{ESTRUS BEHAVIOUR AND REPRODUCTIVE TRAITS OF PULAWSKA GILTS ASSOCIATED WITH SELECTED GENE POLYMORPHISMS*}

\author{
Marek Babicz'1, Marcin Pastwa', Magdalena Szyndler-Nędza², Anna Kozubska-Sobocińska ${ }^{3}$, \\ Barbara Danielak-Czech ${ }^{3}$,Kinga Kropiwiec-Domańska ${ }^{1 *}$, Ewa Skrzypczak ${ }^{4}$, Brygida Ślaska ${ }^{5}$, \\ Damian Kapusta ${ }^{1}$
}

\author{
${ }^{1}$ Institute of Animal Breeding and Biodiversity Conservation, Faculty of Biology, Animal Sciences \\ and Bioeconomy, University of Life Sciences in Lublin, Akademicka 13, 20-950 Lublin, Poland \\ ${ }^{2}$ Department of Pig Breeding, National Research Institute of Animal Production, \\ 32-083 Balice n. Kraków, Poland \\ ${ }^{3}$ Department of Animal Molecular Biology, National Research Institute of Animal Production, \\ 32-083 Balice n. Kraków, Poland \\ ${ }^{4}$ Department of Animal Breeding and Product Quality Assessment, Poznań University of Life Sciences, \\ Złotniki, Słoneczna 1, 62-002 Suchy Las, Poland \\ ${ }^{5}$ Institute of Biological Basis of Animal Production, Faculty of Biology, \\ Animal Sciences and Bioeconomy, University of Life Sciences in Lublin, Akademicka 13, \\ 20-950 Lublin, Poland \\ •Corresponding author: kinga.kropiwiec@up.lublin.pl
}

\begin{abstract}
Searching for the associations between the gene polymorphism and the reproductive traits is essential in defining the genetic native breed specificity, which distinguishes them from the other breeds. The aim of our study was to determine the associations between mutations in the PRL, PRLR, PTGS2, FUT1 genes and sexual and periparturient activity in native Pulawska gilts. The analysis included 72 animals which gave birth to the first litter. Evaluation of the productive value of gilts accounted for indicators of sexual and periparturient activity as well as reproductive traits. The biological material for molecular analyses was obtained from the hair roots of the gilts. The genotype was verified by PCR RFLP analysis. The primers and PCR conditions were determined on the basis of available literature data. Statistically significant differences $(P \leq 0.05)$ were found at the PRL locus: gilts of $A A$ genotypes (Ins/Ins) at the $P R L$ locus were characterised by longest farrowing duration compared to gilts of $A B$ genotype $(\mathrm{P} \leq 0.05)$. The analysis of $P R L R$ gene showed that gilts of $T T$ genotype revealed a tendency for later occurrence of estrus signs (first and second estrus) and for the markedly longest farrowings $(\mathrm{P} \leq \mathbf{0 . 0 5})$. With regard to PTGS2 and FUT1 loci, no significant differences were found in the parameters of sexual and periparturient activity of the gilts. However, gilts of $F U T 1$ GG genotype gave birth to and reared the largest first litters $(\mathrm{P} \leq \mathbf{0 . 0 5})$. The results of the studies expand the knowledge about the genetic structure and productivity of Pulawska gilts.
\end{abstract}

Key words: native Pulawska gilts, sexual and periparturient activity, FUT1, PRL, PRLR, PTGS2

*Work financed from statutory activity of the Institute of Animal Breeding and Biodiversity Conservation, Department of Pig Breeding and Biotechnology, project no. ZKC/DS-4. 
In conservation breeds of pigs, often unsatisfactory fattening and slaughter traits are compensated for by good reproductive parameters and adaptive capabilities (Traspov et al., 2016; Mujibi et al., 2018). For these reasons, Polish pig breeders and producers use Pulawska pigs as a maternal component due to their high reproductive value (number of piglets born and reared) and biological value of litters, resulting among others from the high milk yield of the mothers (Stasiak et al., 2006: Babicz et al., 2017 b). Many observations have shown that Pulawska sows are characterised by particularly beneficial maternal characteristics such as maternal responsiveness and low incidence of aggression towards offspring, as well as showing strong signs of estrus, which has a positive influence on reproductive indicators (Babicz et al., 2014, $2017 \mathrm{a}, \mathrm{b}, 2019)$. Also stressed is the potential resistance of Pulawska pigs to variable environmental conditions and the relatively low reactivity to stress stimuli (Babicz et al., 2016). Breeding progress for productive traits of farm animals can be achieved through selection of animals with high genetic merit. Therefore, research has been done on genes with potential effects on traits important for breeding (Zhang et al., 2014). In the case of reproductive traits, research carried out to date has focused on polymorphisms in genes such as PRL (Mazurowski et al., 2013; Babicz et al., 2017 b), PRLR (Mihailov et al., 2014; Mencik et al., 2015; Putnova et al., 2002), RBP4 (Spotter et al., 2009; Terman et al., 2011), MC4R (Szyndler-Nędza et al., 2016), GH1 (Kmieć et al., 2008), PTGS2 (COX2) (Ding et al., 2006; Sironen et al., 2010), FSHB (Polasik et al., 2016) FUT1 and ESR (Horak et al., 2005), GPR54 (Wu et al., 2019) and RYR1 (Babicz et al., 2012; Szyndler-Nędza et al., 2019).

Few studies address the association between gene polymorphism and sexual activity of young females, which is one of the major traits affecting fertilisation success in gilts (Babicz et al., 2011, 2014, 2019). There are also no studies concerning the effect of gene locus polymorphism on periparturient activity of the sows. Borell et al. (2007) report that parturition and early lactation are the periods of important behavioural and physiological changes in the sow's body. The restrictions applied during that time are a source of frustration leading, among others, to activation of neuroendocrine pathways that control parturition, colostrum and milk production, and litter survival.

In view of the above, research was conducted on genes whose products are involved in reproductive and behavioural processes and in the body's immune response. These include PRL, PRLR, PTGS2 and FUT1. Prolactin is an important hormone regulating mammary gland function; it is responsible for the establishment and maintenance of lactation, osmoregulation (water and electrolyte balance) and it also influences the behaviour of animals (Freeman et al., 2000; Saleem et al., 2018).

Prostaglandin-endoperoxide $\mathrm{G} / \mathrm{H}$ synthase-2 (PTGS2), also known as cyclooxygenase 2 , is involved together with cyclooxygenase 1 in the conversion of arachidonic acid to prostanoids, i.e. prostaglandin H (PGH2) (Vane et al., 1998). The prostaglandins synthesised in the presence of $C O X$ play key roles in the reproductive system, e.g. during ovulation, fertilisation, embryo implantation and parturition, which has caused PTGS2 to be recognised as a gene with a potentially large impact on reproductive traits in animals (Ding et al., 2006; Sugimoto et al., 2015). 
The FUT1 gene is considered a potential marker for resistance to edema disease in pigs (Bao et al., 2012; Wang et al., 2012) and for reproductive performance traits of sows (Horak et al., 2005). But the results of research for reproductive performance are discrepant.

The aim of the study was to determine the associations between $P R L, P R L R, P T G S 2$, and FUT1 genes polymorphisms and reproductive traits in native Pulawska gilts.

\section{Material and methods}

The analysis included 72 Pulawska gilts, which gave birth to the first litter and were kept in 15 family farms as part of the Conservation Programme for Pulawska Pig Genetic Resources. In each farm, the experimental gilts were mated to one Pulawska boar. The feeding was adjusted to the age and physiological status of the sows, and housing conditions complied with animal welfare requirements (Journal of Laws 2010 no. 56 item 344 as amended). The performance tests, sexual activity, periparturient activity, and reproductive traits of sows included non-invasive and non-painful live testing. The duration and intensity of estrus and farrowing duration were observed using a camera to minimise stress. The sow's hair used in the molecular analyses was taken by the vet and/or farmer and delivered to the laboratory in specially prepared samples.

\section{Measurement of estrus behaviour and reproductive traits in Pulawska gilts}

Sexual activity for the first and second estrus was determined based on age (days), body weight (kg), duration (days) and intensity of estrus signs (pts.). The intensity was scored on a 3-point scale based on response to a teaser and duration of the mounting attempt, where $1=$ very strong estrus signs, mounting attempt $>30 \mathrm{~s}$; $2=$ strong estrus signs, mounting attempt $20-25 \mathrm{~s} ; 3$ = weak signs of estrus, mounting attempt $<5 \mathrm{~s}$.

Reproductive traits were characterised by age at first farrowing (days), farrowing duration (min.) and placental weight $(\mathrm{kg})$. The reproductive performance of the sows was evaluated based on first parity data: number of piglets born alive per litter (head), number of piglets on d 21 of age (head), average piglet weight at birth (g) and average piglet weight on $\mathrm{d} 21(\mathrm{~g})$.

\section{Analysis of gene polymorphism}

The biological material for molecular analyses was obtained from hair roots of the sows. DNA isolation was performed using a Sherlock AX kit (A\&A Biotechnology) following the manufacturer's procedure. The genotype was verified by PCR RFLP analysis. The primers of the PRL, PRLR, FUT1 genes and PCR conditions were determined on the basis of available literature data (Table 1). For the PRLR gene, the primers were designed using Primer-BLAST (NCBI) and OligoCalc v 3.26 programs, and nucleotide databases (GeneBank ENA) (Table 1), although they concern identification of the SNP polymorphism (rs196956224) in pigs reported by Korwin-Kossakowska et al. (2005). The primer sequences were synthesised by 
Genomed Sp. z o.o. and Sigma-Aldrich Sp. z o.o. PCR was performed with a thermal cycler (PTC-200 Peltier DNA Engine, MJ Research). Each sample of $15 \mu$, prepared for PCR, contained: $7.5 \mu \mathrm{l}$ of RedTaq ${ }^{\circledR}$ ReadyMix $^{\mathrm{TM}}$ PCR Reaction Mix (Sigma-Aldrich), $0.2 \mu \mathrm{l}$ of each primer $(5 \mu \mathrm{M}), 5.9 \mu \mathrm{l}$ of water (SIGMA) and $1.2 \mu \mathrm{l}$ of DNA $(20 \mathrm{ng} / \mu \mathrm{l})$. The PCR products were digested with restriction enzymes adapted using the NEBcutter V2.0. program (Vincze et al., 2003) (Table 1). The PCR products were digested with $1 \mu \mathrm{l}$ each of the enzymes Taal ${ }^{\mathrm{FD}}, \mathrm{Hinfl}^{\mathrm{FD}}$ and $\mathrm{H} h a \mathrm{I}^{\mathrm{FD}}$, and $2 \mu \mathrm{l}$ of the NcoI enzyme (Table 1). The PCR-RFLP methods were designed and endonucleases selected to digest the unique sequences in each PCR product depending on polymorphisms occurrence. Electrophoretic separation of the PCR product for different genes, following digestion with restriction enzymes, was performed in 1.5\% agarose gel (Sigma).

Table 1. Primer sequences, PCR thermal conditions and restriction enzyme digestion products of the analysed genes

\begin{tabular}{|c|c|c|c|}
\hline Gene & Primer sequences $\left(5^{\prime} \rightarrow 3^{\prime}\right)$ & $\mathrm{PCR}^{1}$ & References \\
\hline$\overline{P R L}$ & $\begin{array}{l}\text { F 5'-TTAAGAGGAGATGCGTTACA-3', } \\
\text { R 5'-GAATCAAGGAGAATGAGGTC-3' }\end{array}$ & 298 & Babicz et al., 2008 \\
\hline PRLR & $\begin{array}{l}\text { F 5'-TCCCATGAACCAAGCTCTCACTGAA-3' } \\
\text { R 5'-CGGGGAAGGAAGGGCAACCG-3' }\end{array}$ & 483 & Skrzypczak et al., 2015 \\
\hline PTGS2 & $\begin{array}{l}\text { F 5'-TCCAAACAAGGGCACTCAAAGACAA-3' } \\
\text { R 5'-ACAGCATGATTTCCCTGGGTGGA-3' }\end{array}$ & 655 & $\begin{array}{l}\text { Korwin-Kossakowska et } \\
\text { al., } 2005\end{array}$ \\
\hline FUT1 & $\begin{array}{l}\text { F 5'-CTTCAGCCAGGGCTCCTTTAAG-3' } \\
\text { R 5'- CTTCCTGAACGTCTATCAAGACC -3' }\end{array}$ & 421 & Meijerink et al., 1997 \\
\hline
\end{tabular}

Temperature programme depending on PCR phase

$\begin{array}{lccccccc} & \mathrm{ID} & \mathrm{D} & \mathrm{A} & \mathrm{E} & \mathrm{n} & \mathrm{FE} & \mathrm{T}_{\text {stop }} \\ \text { PRL } & 95^{\circ} \mathrm{C}, 5^{\prime} & 95^{\circ} \mathrm{C}, 35^{\prime \prime} & 58^{\circ} \mathrm{C}, 35^{\prime \prime} & 725^{\circ} 5 \mathrm{C}, 35^{\prime \prime} & 36 & 72^{\circ} \mathrm{C}, 6^{\prime} & 4^{\circ} \mathrm{C} \sim \\ \text { PRLR } & & 95^{\circ} \mathrm{C}, 35^{\prime \prime} & 62^{\circ} \mathrm{C}, 35^{\prime \prime} & 72^{\circ} \mathrm{C}, 40^{\prime \prime} & 36 & & \\ \text { PTGS2 } & 95^{\circ} \mathrm{C}, 5^{\prime} & 95^{\circ} \mathrm{C}, 40^{\prime \prime} & 62^{\circ} \mathrm{C}, 35^{\prime \prime} & 72^{\circ} \mathrm{C}, 50^{\prime \prime} & 37 & 72^{\circ} \mathrm{C}, 6^{\prime} & 4^{\circ} \mathrm{C} \sim \\ \text { FUT1 } & & 95^{\circ} \mathrm{C}, 35^{\prime \prime} & 56^{\circ} \mathrm{C}, 35^{\prime \prime} & 72^{\circ} \mathrm{C}, 40^{\prime \prime} & 36 & & \end{array}$

\begin{tabular}{|c|c|c|c|c|c|}
\hline & $\begin{array}{c}\text { Restriction } \\
\text { enzyme }\end{array}$ & Identified sequence & $\begin{array}{l}\text { Temp. } \\
\left({ }^{\circ} \mathrm{C}\right)\end{array}$ & Time & $\begin{array}{l}\text { Length of fragments } \\
\text { (bp) }\end{array}$ \\
\hline$P R L$ & $\mathrm{~T} a a \mathrm{I}^{\mathrm{FD}, 2}$ & $5^{\prime}-\mathrm{ACN} \downarrow \mathrm{GT}-3^{\prime}$ & 37 & $5 \mathrm{~min}$ & $\begin{array}{l}\text { ins: } 212,86 \\
\text { del: } 289\end{array}$ \\
\hline PRLR & $\mathrm{NcoI}{ }^{3}$ & $5^{\prime}-\mathrm{C} \downarrow$ CATGG-3' & 37 & $2 \mathrm{~h}$ & $\begin{array}{c}\text { AA: } 365,118 \\
\text { AT: } 483,365,118 \\
\text { TT: } 483\end{array}$ \\
\hline$P T G S 2$ & $\mathrm{Hinf} \mathrm{I}^{\mathrm{FD}, 2}$ & 5'-G $\downarrow$ ANTC-3' & 37 & $5 \mathrm{~min}$ & $\begin{array}{c}\text { TT: } 288,176,137,54 \text { CT: } 288, \\
176,137,114,62,54 \\
\text { CC: } 288,137,114,62,54\end{array}$ \\
\hline FUT1 & $\mathrm{H} h a \mathrm{I}^{\mathrm{FD}, 2}$ & $5^{\prime}-\mathrm{GCG} \downarrow \mathrm{C}-3^{\prime}$ & 37 & $5 \mathrm{~min}$ & $\begin{array}{c}\text { AA: } 328,93 \\
\text { AG: } 87,93,241,328 \\
\text { GG: } 241,93,87\end{array}$ \\
\hline
\end{tabular}

${ }^{1}$ - length of PCR product denoted in number of base pairs.

ID - initial denaturation; D - denaturation; A - annealing; $\mathrm{E}$ - extension; $\mathrm{n}$ - number of PCR cycles (each cycle consists of ID, followed by D and A); FE - final extension of amplification products; $\mathrm{T}_{\text {STоP }}$ - temperature maintained after the end of PCR.

FD - line of fast digestion enzymes (FastDigest).

Enzyme producers: ${ }^{2}$ - Thermo Fisher Scientific Inc.; ${ }^{3}$ - EURx Ltd. 


\section{Statistical analysis}

Statistical analysis was performed with the GLM procedure and Genetica (SAS Institute, USA). The Hardy-Weinberg equilibrium was assessed by using the Court Lab - HW calculator. The statistical model used to calculate the effect of polymorphism of the analysed gene was:

$$
y_{i j k l m}=\mu+H_{i}+P R L_{j}+P R L R_{k}+P T G S 2_{l}+F U T 1_{m}+e_{i j k l m n}
$$

where:

$y_{i j k l m}$ - trait phenotypic value,

$\mu$ - population average,

$H_{i}$ - fixed effect of the herd (absorption of effect),

$P R L_{j}$ - constant genotype effect in the examined locus $P R L(\mathrm{j}=1,2,3)$,

$P R L R_{k}$ - constant genotype effect in the examined locus $P R L R(\mathrm{k}=1,2,3)$,

$P T G S 2_{l}$ - constant genotype effect in the examined locus PTGS2 $(1=1,2,3)$,

FUT1 ${ }_{m}$ - constant genotype effect in the examined locus FUT1 $(\mathrm{m}=1,2,3)$,

$e_{i j k l m}$ - random error.

Absorption of the effect of the herd was used in the calculations. The model did not take into account the effect of the season and year. The study was carried out in one year at a similar time.

Statistically non-significant effects were removed from the linear model and the calculations performed again.

The calculations were made with the SAS statistical package. The level of the analysed traits was presented as least square means (LSM) while giving the standard errors (SE). The procedure used Tukey-Kramer adjustment for multiple comparisons. Differences between traits were analysed at $\mathrm{P} \leq 0.01$ and $\mathrm{P} \leq 0.05$ levels of significance.

\section{Results}

\section{Genetic variation of PRL, PRLR, PTGS2 and FUT1 loci in Pulawska gilts}

Polymorphism of the prolactin gene (PRL; rs 789846153), associated with the presence (insertion) or absence (deletion) of 11 nucleotide DNA fragment in the 3'UTR region of exon 5 was identified with the TaaI enzyme. As a result of digestion, three genotypes were determined in the studied population of gilts: AA (Ins/ Ins), AB (Ins/Del) and BB (Del/Del) (Babicz et al., 2008).

Non-synonymous substitution (SNP: rs45435438) in exon 8 of the prolactin receptor gene (PRLR) was identified with the NcoI enzyme. As a result of digestion, $A A, A T$ and $T T$ genotypes were identified. Substitution at position 1528 (c.1528A > T) of the gene results in the presence of methionine in place of leucine, at position 510 (p.Met510Leu) of the amino acid chain of the receptor protein (Skrzypczak et al., 2015). 
The polymorphism in exon 2 of the PTGS2 gene (SNP: rs196956224) was examined using the Hinfl enzyme, and the digestion revealed 2 gilt genotypes: $A G$ and $G G$ (Korwin-Kossakowska et al., 2005).

Non-synonymous substitution in exon 2 of the FUT1 gene (SNP: rs335979375) at position 307 (NM_214068.2: c.307A $>$ G), associated with sequence alteration in the protein amino acid chain (p.Thr103Ala) was identified with the HhaI enzyme. As a result of digestion, 3 genotypes were identified: $A A, A G$ and $G G$ (Meijerink et al., 1997).

Polymorphism in selected gene loci was determined in the studied population of Pulawska gilts (Table 2). Two genotypes, $A G$ and $G G$, were identified at the PTGS2 locus. Three genetic forms were identified at the locus of other genes. The highest frequency was observed for alleles PRL B, PRLR A, PTGS2 G and FUT1 A.

Among genotypes, frequency was highest for heterozygotes $A G$ (PTGS2 and FUT1) and lowest for homozygotes $G G$ (FUT1). Analysis of the frequency of genotypes of these polymorphisms - in accordance with the Hardy-Weinberg law showed that breeds were not at genetic equilibrium.

Table 2. Analysis of the distribution of alleles and genotypes in the analysed population of animals in accordance with the Hardy-Weinberg law

\begin{tabular}{|c|c|c|c|c|c|c|}
\hline \multirow{2}{*}{ Gene } & \multirow{2}{*}{ No. of sows } & \multirow{2}{*}{ Genotype } & \multicolumn{3}{|c|}{ Frequency } & \multirow{2}{*}{$\begin{array}{c}\text { HWE } \\
\text { P-value }\end{array}$} \\
\hline & & & genotype & & & \\
\hline \multirow[t]{3}{*}{$\overline{P R L^{1}}$} & 15 & $A A$ & 0.208 & $A$ & 0.389 & \\
\hline & 26 & $A B$ & 0.361 & & & 0.0163 \\
\hline & 31 & $B B$ & 0.431 & $B$ & 0.611 & \\
\hline \multirow[t]{3}{*}{ PRLR } & 20 & $A A$ & 0.278 & $A$ & 0.583 & \\
\hline & 44 & $A T$ & 0.611 & & & 0.0102 \\
\hline & 8 & $T T$ & 0.111 & $T$ & 0.417 & \\
\hline \multirow[t]{3}{*}{ PTGS2 } & 0 & $A A$ & 0.000 & $A$ & 0.319 & \\
\hline & 46 & $A G$ & 0.639 & & & 0.000 \\
\hline & 26 & $G G$ & 0.361 & $G$ & 0.681 & \\
\hline \multirow[t]{3}{*}{ FUT1 } & 22 & $A A$ & 0.306 & $A$ & 0.604 & \\
\hline & 43 & $A G$ & 0.597 & & & 0.0129 \\
\hline & 7 & $G G$ & 0.097 & $G$ & 0.396 & \\
\hline
\end{tabular}

${ }^{1}$ - alleles $A$ and $B$ in the prolactin gene correspond with Ins/Del type polymorphism ( $A A$ : Ins/Ins, $A B$ : Ins/Del; BB: Del/Del).

HWE - Hardy-Weinberg equilibrium.

\section{Associations of gene polymorphisms with the values of analysed traits $P R L$ gene polymorphism}

The age and body weight of the gilts from the different genetic groups during first and second estrus were uniform (Table 3). Distinct but statistically non-significant differences were observed in the intensity of estrus signs; in the sows of $A A$ genotype this intensity was by far the lowest during both the first and second estrus. There 
were no significant differences in the age of the sows at first farrowing and in the weight of expelled placenta. In turn, the analysis of farrowing duration showed that the sows of genotype $A A$ took 84 minutes longer to farrow on average compared to heterozygotes $A B$, with a statistically significant difference $(\mathrm{P} \leq 0.05)$. The number of live born piglets, calculated for the first reproductive cycle, as well as the mean body weight of piglets at birth remained at a similar level regardless of genotype group.

Table 3. Least square means (LSM) and standard errors (SE) for sexual activity parameters, farrowing indicators of the gilts and reproductive performance traits of first- and second-parity sows depending on PRL locus genotype (rs 789846153)

\begin{tabular}{|c|c|c|c|}
\hline \multirow{2}{*}{ Trait } & $A A$ & $A B$ & $B B$ \\
\hline & $\mathrm{LSM} \pm \mathrm{SE}$ & $\mathrm{LSM} \pm \mathrm{SE}$ & $\mathrm{LSM} \pm \mathrm{SE}$ \\
\hline \multicolumn{4}{|c|}{ Sexual activity parameters of first estrus } \\
\hline Age (d) & $203.56 \pm 2.92$ & $205.44 \pm 2.11$ & $205.94 \pm 2.06$ \\
\hline Body weight (kg) & $86.46 \pm 1.98$ & $85.74 \pm 1.17$ & $84.12 \pm 1.40$ \\
\hline Duration $(\mathrm{d})$ & $2.00 \pm 0.20$ & $2.44 \pm 0.16$ & $2.28 \pm 0.14$ \\
\hline Intensity (pts.) & $1.56 \pm 0.23$ & $2.11 \pm 0.19$ & $2.17 \pm 0.16$ \\
\hline \multicolumn{4}{|c|}{ Sexual activity parameters of second estrus } \\
\hline Age (d) & $224.33 \pm 2.94$ & $226.00 \pm 2.13$ & $226.33 \pm 2.08$ \\
\hline Body weight (kg) & $101.33 \pm 2.19$ & $100.00 \pm 1.18$ & $99.11 \pm 1.55$ \\
\hline Duration (d) & $2.78 \pm 0.20$ & $2.67 \pm 0.15$ & $2.39 \pm 0.14$ \\
\hline Intensity (pts.) & $2.11 \pm 0.26$ & $2.44 \pm 0.22$ & $2.28 \pm 0.19$ \\
\hline \multicolumn{4}{|c|}{ Farrowing indicators } \\
\hline Age at first farrowing (d) & $325.78 \pm 10.55$ & $336.56 \pm 8.47$ & $328.83 \pm 7.46$ \\
\hline Farrowing duration (min) & $291.56 \mathrm{a} \pm 22.48$ & $208.33 \mathrm{~b} \pm 12.33$ & $233.06 \pm 15.89$ \\
\hline Placental weight $(\mathrm{kg})$ & $3.11 \pm 0.23$ & $3.10 \pm 0.12$ & $3.24 \pm 0.16$ \\
\hline \multicolumn{4}{|c|}{ Reproductive traits of first parity } \\
\hline Number of live born piglets (head) & $10.67 \pm 0.42$ & $10.56 \pm 0.36$ & $10.94 \pm 0.29$ \\
\hline Number of piglets at $21 \mathrm{~d}$ (head) & $9.33 \pm 0.38$ & $9.44 \pm 0.21$ & $9.83 \pm 0.27$ \\
\hline Mean weight of piglet at birth (g) & $1284.44 \pm 59.81$ & $1244.44 \pm 49.72$ & $1286.11 \pm 42.29$ \\
\hline Mean weight of piglet at $21 \mathrm{~d}(\mathrm{~g})$ & $5484.44 \pm 268.22$ & $5391.11 \pm 206.44$ & $5361.11 \pm 189.66$ \\
\hline
\end{tabular}

$\mathrm{a}, \mathrm{b}-$ means in rows with different letters differ significantly at $\mathrm{P} \leq 0.05$.

\section{PRLR gene polymorphism}

Significant differences $(\mathrm{P} \leq 0.05)$ were found in the age of the gilts during first and second estrus (Table 4), and when the signs of estrus were observed, the gilts of $T T$ genotype were older than $A A$ gilts by $15 \mathrm{~d}$ on average. No statistically significant differences were found in the values of the other indicators. The analysis of farrowing duration showed that the sows of $T T$ genotype took by far the longest to farrow. Farrowing time of TT sows was on average 122 min longer than that of $A T$ heterozygotes, with a statistically significant difference $(\mathrm{P} \leq 0.05)$. The analysis of 
reproductive performance depending on $P R L R$ locus genotype demonstrated that the differences between traits of analysed litter, were statistically non-significant.

Table 4. Least square means (LSM) and standard errors (SE) for sexual activity parameters, farrowing indicators of the gilts and reproductive performance traits of first parity sows depending on PRLR locus genotype (rs 45435438)

\begin{tabular}{|c|c|c|c|}
\hline \multirow{2}{*}{ Trait } & $A A$ & $A T$ & $T T$ \\
\hline & $\mathrm{LSM} \pm \mathrm{SE}$ & $\mathrm{LSM} \pm \mathrm{SE}$ & $\mathrm{LSM} \pm \mathrm{SE}$ \\
\hline \multicolumn{4}{|c|}{ Sexual activity parameters of first estrus } \\
\hline Age (d) & $200.45 \mathrm{a} \pm 2.38$ & $206.61 \pm 1.65$ & $215.50 \mathrm{~b} \pm 5.58$ \\
\hline Body weight (kg) & $82.08 \pm 1.67$ & $86.04 \pm 1.16$ & $91.05 \pm 3.92$ \\
\hline Duration (d) & $2.27 \pm 0.19$ & $2.26 \pm 0.13$ & $2.00 \pm 0.44$ \\
\hline Intensity (pts.) & $2.00 \pm 0.22$ & $2.04 \pm 0.15$ & $1.50 \pm 0.51$ \\
\hline \multicolumn{4}{|c|}{ Sexual activity parameters of second estrus } \\
\hline Age (d) & $221.18 \mathrm{a} \pm 2.40$ & $227 \pm 1.66$ & $236.50 \mathrm{~b} \pm 5.64$ \\
\hline Body weight (kg) & $97.45 \pm 1.94$ & $100.83 \pm 1.34$ & $102.5 \pm 4.54$ \\
\hline Duration (d) & $2.64 \pm 0.18$ & $2.48 \pm 0.13$ & $3.00 \pm 0.43$ \\
\hline Intensity (pts.) & $1.91 \pm 0.23$ & $2.43 \pm 0.16$ & $2.50 \pm 0.54$ \\
\hline \multicolumn{4}{|c|}{ Farrowing indicators } \\
\hline Age at first farrowing $(\mathrm{d})$ & $324.27 \pm 9.28$ & $335.04 \pm 6.42$ & $303.50 \pm 21.76$ \\
\hline Farrowing duration (min) & $268.18 \pm 19.98$ & $219.96 \mathrm{a} \pm 13.82$ & $342.50 \mathrm{~b} \pm 46.85$ \\
\hline Placental weight $(\mathrm{kg})$ & $3.18 \pm 0.21$ & $3.18 \pm 0.14$ & $2.99 \pm 0.48$ \\
\hline \multicolumn{4}{|c|}{ Reproductive traits of first parity } \\
\hline Number of live born piglets (head) & $10.82 \pm 0.37$ & $10.87 \pm 0.25$ & $9.50 \pm 0.86$ \\
\hline Number of piglets at $21 \mathrm{~d}$ (head) & $9.55 \pm 0.34$ & $9.74 \pm 0.23$ & $8.50 \pm 0.79$ \\
\hline Mean weight of piglet at birth (g) & $1246.36 \pm 53.80$ & $1293.91 \pm 37.20$ & $1220.00 \pm 126.17$ \\
\hline Mean weight of piglet at $21 \mathrm{~d}(\mathrm{~g})$ & $5458.18 \pm 230.08$ & $5460.87 \pm 159.11$ & $4370.00 \pm 539.58$ \\
\hline
\end{tabular}

$\mathrm{a}, \mathrm{b}-$ means in rows with different letters differ significantly at $\mathrm{P} \leq 0.05$.

\section{PTGS2 gene polymorphism}

Sexual activity parameters of the gilts (Table 5) were at a comparable level in both genotype groups under analysis. The analysis of farrowing duration showed that it was shorter in $A G$ heterozygotes, despite the fact that these sows farrowed and reared larger litters with lower birth weight. However, the observed differences in the values of the traits were not significant.

\section{FUT1 gene polymorphism}

No significant differences were noted in the sexual activity indicators and in the farrowing parameters of the gilts (Table 6). The analysis of reproductive performance traits showed that the sows of $G G$ genotype $(\mathrm{P} \leq 0.05)$ farrowed and reared more nu- 
merous litters. Furthermore, piglets born to $G G$ homozygotes had the highest weight gains and achieved at $21 \mathrm{~d}$ of age the highest average body weight, despite the fact that they were characterised by the lowest birth weight.

Table 5. Least square means (LSM) and standard errors (SE) for sexual activity parameters, farrowing indicators of the gilts and reproductive performance traits of first parity sows depending on PTGS2 locus genotype (rs196956224)

\begin{tabular}{c|c|c}
\hline \multirow{2}{*}{ Trait } & $A G$ & $G G$ \\
\cline { 2 - 3 } & $\mathrm{LSM} \pm \mathrm{SE}$ & $\mathrm{LSM} \pm \mathrm{SE}$ \\
\hline
\end{tabular}

\section{Sexual activity parameters of first estrus}

Age (d)

Body weight $(\mathrm{kg})$

Duration (d)

Intensity (pts.)

Body weight $(\mathrm{kg})$

Duration (d)

Intensity (pts.)

Age at first farrowing (d)

Farrowing duration (min)

Placental weight $(\mathrm{kg})$
$204.04 \pm 1.78$

$85.29 \pm 1.24$

$2.26 \pm 0.13$

$2.00 \pm 0.15$

Sexual activity parameters of second estrus

$224.52 \pm 1.79$

$100.57 \pm 1.35$

$2.57 \pm 0.13$

$2.30 \pm 0.16$

\section{Farrowing indicators}

$332.30 \pm 6.52$

$233.22 \pm 15.15$

$3.24 \pm 0.14$

$207.31 \pm 2.36$

$84.79 \pm 1.65$

$2.23 \pm 0.17$

$2.00 \pm 0.20$

$227.92 \pm 2.38$

$98.69 \pm 1.80$

$2.54 \pm 0.17$

$2.23 \pm 0.22$
$325.92+8.67$

$256.15 \pm 20.15$

$3.05 \pm 0.19$

\section{Reproductive traits of first parity}

Number of live born piglets (head)

$10.96 \pm 0.25$

$10.46 \pm 0.34$

Number of piglets at $21 \mathrm{~d}$ (head)

$9.74 \pm 0.24$

$9.38 \pm 0.31$

Mean weight of piglet at birth (g)

$1252.17 \pm 36.47$

$1316.15 \pm 48.50$

Mean weight of piglet at $21 \mathrm{~d}(\mathrm{~g})$

$5333.04 \pm 164.57$

$5516.92 \pm 218.90$

Table 6. Least square means (LSM) and standard errors (SE) for sexual activity parameters, farrowing indicators of the gilts and reproductive performance traits of first parity sows depending on FUT1 locus genotype (rs335979375)

\begin{tabular}{c|c|c|c}
\hline \multirow{2}{*}{ Trait } & $A A$ & $A G$ & $G G$ \\
\cline { 2 - 4 } & $\mathrm{LSM} \pm \mathrm{SE}$ & $\mathrm{LSM} \pm \mathrm{SE}$ & $\mathrm{LSM} \pm \mathrm{SE}$ \\
\hline 1 & 2 & 3 & 4 \\
\hline
\end{tabular}

Sexual activity parameters of first estrus

$\begin{array}{lrrr}\text { Age (d) } & 204.36 \pm 2.61 & 206.13 \pm 1.80 & 199.50 \pm 6.11 \\ \text { Body weight (kg) } & 83.31 \pm 1.78 & 85.93 \pm 1.23 & 85.50 \pm 4.18 \\ \text { Duration (d) } & 2.18 \pm 0.19 & 2.30 \pm 0.13 & 2.00 \pm 0.44 \\ \text { Intensity (pts.) } & 2.27 \pm 0.22 & 1.87 \pm 0.15 & 2.00 \pm 0.50\end{array}$


Table 6 - contd.

\begin{tabular}{lcccc}
\hline & & 2 & 3 & 4 \\
\hline \multicolumn{4}{c}{ Sexual activity parameters of second estrus } \\
Age (d) & $225.00 \pm 2.62$ & $226.65 \pm 1.81$ & $219.50 \pm 6.14$ \\
Body weight (kg) & $98.36 \pm 1.97$ & $100.74 \pm 1.36$ & $98.50 \pm 4.63$ \\
Duration (d) & $2.73 \pm 0.18$ & $2.48 \pm 0.13$ & $2.50 \pm 0.43$ \\
Intensity (pts.) & $2.09 \pm 0.24$ & $2.35 \pm 0.16$ & $2.50 \pm 0.56$ \\
& Farrowing indicators & \\
Age at first farrowing (d) & $325.18 \pm 9.00$ & $328.48 \pm 6.23$ & $374.00 \pm 21.11$ \\
Farrowing duration (min) & $246.73 \pm 21.19$ & $247.61 \pm 14.66$ & $142.50 \pm 49.70$ \\
Placental weight (kg) & $3.09 \pm 0.20$ & $3.16 \pm 0.14$ & $3.76 \pm 0.47$ \\
& Reproductive traits of first parity & \\
Number of live born piglets (head) & $11.36 \mathrm{a} \pm 0.32$ & $10.35 \mathrm{a} \pm 0.22$ & $12.50 \mathrm{~b} \pm 0.76$ \\
Number of piglets at 21 d (head) & $9.73 \pm 0.32$ & $9.39 \mathrm{a} \pm 0.22$ & $11.50 \mathrm{~b} \pm 0.74$ \\
Mean weight of piglet at birth (g) & $1280.91 \pm 54.04$ & $1279.57 \pm 37.37$ & $1195.00 \pm 126.74$ \\
Mean weight of piglet at 21 d (g) & $5196.36 \pm 239.26$ & $5479.13 \pm 165.46$ & $5600.00 \pm 561.11$ \\
\hline
\end{tabular}

$\mathrm{a}, \mathrm{b}-$ means in rows with different letters differ significantly at $\mathrm{P} \leq 0.05$.

\section{Discussion}

The risk of the native Pulawska pigs becoming extinct has caused this breed to be included in the genetic resources conservation programme. The main objective of conservation breeding is to increase populations to the level that makes them stable and biologically sustainable, while maintaining genetic distinctiveness and withinbreed variation (Babicz et al., $2017 \mathrm{a}, \mathrm{b}$ ). In this context, it is important to determine the breed's genetic structure and to analyse associations between specific genetic markers and reproduction traits of pigs (Wu et al., 2019; Onteru et al., 2009).

The lack of genetic equilibrium in the analysed gene polymorphisms, revealed in the population under study, suggests the possible effect of selective breeding which, according to the principles of the conservation programme for the Pulawska breed, aims to minimise population inbreeding and improve reproductive traits while maintaining fattening and slaughter traits at a constant level. Because the reproductive performance traits of sows show a low coefficient of heritability (Tyra and Różycki, 2004), it takes a relatively long time to improve them using traditional methods. In this respect, identification of the associations between the polymorphism of genes and reproductive performance traits of the sows may accelerate breeding progress.

The Ins/Del type polymorphism, identified by Babicz et al. (2008) in the prolactin gene (rs 789846153), was used to search for associations with the reproductive characteristics of highly productive maternal breeds of pigs (Mazurowski et al., 2013; Milczewska et al., 2011). The authors of these studies showed this polymor- 
phism had no significant effect on age at first farrowing in Polish Large White and Polish Landrace gilts, and on the number of piglets born and reared. Likewise, our study showed no statistically significant effect of the polymorphism of this gene on age at first farrowing in Pulawska gilts, and on indicators of sexual activity during first and second estrus. Neither were there any differences in the number of piglets in the first litter. Significant differences $(\mathrm{P} \leq 0.05)$ were noted in the duration of farrowing (Table 3), with $A A$ sows having the longest farrowing time and $A B$ heterozygotes the shortest. This information could be used in productive herds of Pulawska pigs that produce fatteners. Reproductive use of $P R L A B$ heterozygous gilts will help to improve farrowing management and reduce handling costs. For the prolactin receptor, Van Rens and Van der Lende (2002) reported that homozygous BB (PRLR/AluI) gilts were significantly $(\mathrm{P} \leq 0.05)$ younger than $A A$ gilts, by an average of $41 \mathrm{~d}$ at first estrus and by $49 \mathrm{~d}$ at first insemination. No significant differences were found in gestation length and placental weight between the analysed sow genotypes, although $B B$ homozygotes had higher mean placental weight but these sows gave birth to the smallest litters $(\mathrm{P} \leq 0.05)$.

In our study, differences in the values of traits between the genotypes analysed at the PRLR/NcoI locus (rs45435438) were only shown for the age of sows during estrus and for the duration of first farrowing (Table 4). At first and second estrus, the oldest sows among all the genotype groups were $T T$ homozygotes, with a significant difference between the $T T$ and $A A$ sows $(\mathrm{P} \leq 0.05)$. TT sows gave birth to first offspring much earlier (by an average of $21 \mathrm{~d}$ compared to $A A$ homozygotes and by 32 d compared to $A T$ heterozygotes) (this difference was not significant), but at the same time the $T T$ sows had longer $(\mathrm{P} \leq 0.05)$ farrowing duration $(345 \mathrm{~min}$ in $T T$ sows and $220 \mathrm{~min}$ in $A T$ sows). We did not show an unambiguously favourable effect of genotype at the $P R L R$ locus on the indicators of litter size and piglet weight, although the highest values were typical for heterozygotes and the lowest values for TT homozygotes. Omelka et al. (2008) showed a significantly higher $(\mathrm{P} \leq 0.01)$ total number of piglets born in $A A$ homozygous ( $P R L R / \mathrm{A} l u \mathrm{I})$ sows of Slovak Landrace, Large White and White Meaty breeds. Mihailov et al. (2014) showed that $B B$ homozygotes $(P R L R / \mathrm{A} l u \mathrm{I})$ gave birth to markedly more piglets $(\mathrm{P} \leq 0.01)$, regardless of breed. A similar relationship for the total number of piglets born and number of piglets born alive, but only in the first and second litter, was reported by Mencik et al. (2015). The analysis of third and fourth parities and all parities (1-4) revealed the advantage of sows with $A A$ genotype over the others.

Our study of the association between PTGS2 locus polymorphism (rs196956224) and the level of analysed indicators showed no significant relationships for sexual and periparturient activity of the gilts, or for traits related to litter size and weight. Sironen et al. (2010) - based on the results from the second and subsequent litters - demonstrated that the identified allele 1 (notation of the discussed polymorphism used by the authors) at the COX2 locus (PTGS2) was significantly related to a greater number of piglets born when compared to allele 2 (an increase of 0.31 ; additive effect found). Nevertheless, as in our study, this relationship was not observed for first litters. Horak et al. (2005), who analysed parities 1-6 in a population of Prestice Black-Pied sows, showed higher values of reproductive parameters in sows of FUT1 
$G G$ genotype compared to those of $A A$ genotype. Different results were obtained by Zhu et al. (2014) when analysing the reproductive performance of Yorkshire sows. The authors showed that in parities 3-5, sows of $A A$ genotype produced significantly the largest number of piglets. Our results (Table 6) agree with those of Horak et al. (2005). Pulawska sows of FUT1 GG genotype (rs335979375) gave birth to and reared significantly the largest number of piglets in the first litter $(\mathrm{P} \leq 0.05)$, compared to sows of $A G$ and $A A$ genotype. The lowest value of this trait was obtained for the sows of FUT1 AG genotype.

Summing up and generalising the results of our research, it can be stated that gilts of $A A$ genotypes (Ins/Ins) at the PRL locus are characterised by longest farrowing duration compared to gilts of $A B$ genotype. The analysis of the polymorphic associations of the PRLR gene variants did not show statistically significant differences for the performance test indicators in gilts, whereas in $T T$ homozygotes it revealed a tendency for later occurrence of estrus signs (first and second estrus) and for the markedly longest farrowings $(\mathrm{P} \leq 0.05)$. With regard to PTGS2 and FUT1 loci, no statistically significant differences were observed in the indicators related to the level of sexual and periparturient activity in gilts. It was found, however, that females of FUT1 GG genotype produced and reared the largest first litters $(\mathrm{P} \leq 0.05)$.

\section{Conclusions}

The results of the studies presented above expand knowledge about the genetic structure and productivity of Pulawska sows. Searching for the associations between the gene polymorphism and the productive traits is essential to defining the genetically determined breed specificity of these animals which distinguishes them from other breeds.

Our study suggests the association between analysed gene polymorphism and productive traits. Polymorphism in the $P R L$ locus affects farrowing duration. The analysis of the polymorphic associations of the $P R L R$ gene variants revealed a tendency for later occurrence of estrus signs (first and second estrus) and for the markedly longest farrowings. In the case of the FUT1 gene, it was found that polymorphism of the FUT1 locus influences the size of the first litters.

\section{References}

B abicz M., Pierzchała M., Urbański P., Rozempolska-Rucińska I. (2008). An insertion/deletion polymorphism in the $3^{\prime} \mathrm{UTR}$ encoding region of the porcine prolactin $(P R L)$ gene. Anim. Sci. Pap. Rep., 26: 183-189.

Babicz M., Rejduch B., Kozubska-Sobocińska A., Pastwa M., Kasprzyk A., S ta siak A., S e ra fin-Kozak M. (2011). Analysis of sexual activity in gilts in terms of their reproductive value. Ann. Anim. Sci., 11: 241-250.

Babicz M., Skrzypczak E., Rejduch B., Kozubska-Sobocińska A., Chmielo- wi e c-Korzeniows k a A., Kas przak K. (2012). Effect of thermal stress on reproductive performance parameters of sows with defined genotype at the RYR1 locus. Ann. Anim. Sci., 12: 323-333.

Babicz M., Skrzypczak E., Kropiwiec K., Kozubska-Sobocińska A., Danie$-1 \mathrm{ak}-\mathrm{Czech}$ B. (2014). Impact of PRL and FST loci polymorphism on sexual activity of Pulawska gilts. Ann. Anim. Sci., 14: 821-830. 
B a b i c z M., S z y n d l e r - N ę d z a M., S krzy p c zak E., K a s przy k A. (2016). Reproductive performance of native Pulawska and high productivity Polish Landrace sows in the context of stress during the period of early pregnancy. Reprod. Domest. Anim., 51: 91-97.

Babicz M., Danielak-Czech B., Kozubska-Sobocińska A., Łuszczewska-Sierakowska I., Wawrzyniak A., Grzebalska A.M., Kropiwiec-Domańska K. (2017 a). Cytogenetic and molecular studies in conservation breeding of Pulawska breed pigs. Med. Weter., 73: 395-398.

Babicz M., Szyndler-Nędza M., Kasprzyk A., Kropiwiec K. (2017 b). Analysis of maternal traits in native Pulawska sows of known genotype (Ins/Del) at the PRL locus. Ann. Anim. Sci., 17: 13-141.

B abicz M., P a stwa M., S krzy pczak E., Łuszczewska-S i erak ow ska I., Wawrzyni a k A. (2019). Sexual activity of different gilt genotype groups of the Pulawska breed during oestrus. Med. Weter., 75: 50-53.

B a o W.B., Ye L., P an Z.Y., Zhu J., Du Z.D., Zhu G.Q., Huang X.G., Wu S.L. (2012). The effect of mutation at M307 in FUT1 gene on susceptibility of Escherichia coli F18 and gene expression in Sutai piglets. Mol. Biol. Rep., 39: 3131-3136.

B ore 11 E., Dobs on H., Prunier A. (2007). Stress, behaviour and reproductive performance in female cattle and pigs. Horm. Behav., 52: 130-138.

D ing N.S., Ren D.R., Gu o Y.M., R en J., Yan Y., Ma J.W., Chen K.F., Huang L.S. (2006). Genetic variation of porcine prostaglandin-endoperoxide synthase 2 (PTGS2) gene and its association with reproductive traits in an Erhualian x Duroc F2 population. Acta Genet. Sin., 33: 213-219.

Free man M.E., K a n y i c s k a B., L e r a n t A., N a g y G. (2000). Prolactin: structure, function and regulation of secretion. Physiol. Rev., 80: 1523-1631.

H o r a k P., U r b a n T., D v o r a k J. (2005). The FUT1 and ESR genes - their variability and associations with reproduction in Prestice Black-Pied sows. J. Anim. Breed. Genet., 122: 210-213.

K mi é M., Polasik D., N a p i erała F., P ol as i k I. (2008). GH/HaeII and GH/MspI restriction polymorphism in a herd of Polish Large White sows. J. Anim. Vet. Adv., 7: 165-169.

K orw in - Kos s a kow s k a A., K a pelańs ki W., B o ci an M., K a m y c zek M., S ender G. (2005). Preliminary study of the RBP4, EGF and PTGS2 genes polymorphism in pigs and its association with reproduction traits of sows. Anim. Sci. Pap. Rep., 23: 95-105.

Mazurowski A., Milczews ka A., Mroczkowski S. (2013). Influence of the prolactin gene polymorphism on selected reproduction traits in sows of Polish Large White breed. J. Cent. Eur. Agric., 14: 1-10.

Meijerink E., Fries R., Vögeli P., Masabanda J., Wigger G., Stricker C. Neuen s chw ander S., B ert s chinger H.U., Stranzinger G. (1997). Two alpha $(1,2)$ fucosyltransferase genes on porcine chromosome $6 \mathrm{q} 11$ are closely linked to the blood group inhibitor $(S)$ and Escherichia coli F18 receptor (ECF18R) loci. Mamm. Genome, 8: 736-741.

Mencik S., Vuković V., Modrić M., S pehar M., Ostović M., Sus ić V., S toković I., $\mathrm{S}$ a mardzij a M., Ek ert - K a b a 1 in A. (2015). PRLR-AluI gene polymorphism and litter size traits in highly prolific line of Topigs 20 sows. Acta Vet-Beograd., 65: 463-476.

Mihailov N.V., Us atov A.V., Getmantseva L.V., B a k o ev S.U. (2014). Associations between PRLR/AluI gene polymorphism with reproductive, growth, and meat traits in pigs. Cytol. Genet., 48: 323-326.

Milczews k a A., B o g d zińs k a M., Mroczkow s ki S. (2011). How does the polymorphism of the PRL, PRLR, and RYRl genes influence the selected reproduction traits in the Polish Large White and the Polish Landrace sows. Rocz. Nauk. PTZ, 7: 19-26.

Mujibi F.D., Okoth E., Cheruiyot E.K., Onzere C., B ishop R.P., Fèvre E.M., Thomas L., Masembe Ch., Plastow G., Rothschild M. (2018). Genetic diversity, breed composition and admixture of Kenyan domestic pigs. PloS One, 13(1).

O melka R., Martiniakova M., P e s kovi cova D., B a u erova M. (2008). Associations between Alu I polymorphism in the prolactin receptor gene and reproductive traits of Slovak Large White, White Meaty and Landrace pigs. Asian-Australas J. Anim. Sci., 21: 484-488.

On teru S.K., R o s s J.W., R o th s c h ild M.F. (2009). The role of gene discovery, QTL analyses and gene expression in reproductive traits in the pig. Soc. Reprod. Fertil Suppl., 66: 87-102. 
Polasik D., Kumalska M., Sawaragi Y., Żak G., Tyra M., Urbański P., Terman A. (2016). Analysis of FSHB gene polymorphism in Polish Landrace and Polish Large White $\times$ Polish Landrace sows. EJPAU, 19(1).

Putnova L., Knoll A., Dvorak J., Cepica S. (2002). A new HpaII PCR-RFLP within the porcine prolactin receptor $(P R L R)$ gene and study of its effect on litter size and number of teats. J. Anim. Breed. Genet., 119: 57-63.

S a leem M., Martin H., Coates P. (2018). Prolactin biology and laboratory measurement: an update on physiology and current analytical issues. Clin. Biochem. Rev., 39: 3-16.

Sironen A.I., Uimari P., Serenius T., Mote B., Roths child M., Vilk ki J. (2010). Effect of polymorphisms in candidate genes on reproduction traits in Finnish pig populations. J. Anim. Sci., 88: 821-827.

S krzy p c zak E., B a b i c z M., P a s tw a M. (2015). Effect of prolactin receptor (PRLR) and betacasein (CSN2) gene polymorphism on the chemical composition of milk sows. Folia Biol., 63: $135-144$.

S p ot te r A., Muller S., H a m a n n H., D i s 1 O. (2009). Effect of polymorphisms in the genes for LIF and RBP4 on litter size in two German pig lines. Reprod. Domest. Anim., 44: 100-105.

S t a s i a k A., M a z u r A., B a b i c z M., K a m y k P. (2006). Estimation of potential fertility of gilts of three breeds maintained in Poland. Anim. Sci. Pap. Rep., 24: 81-86.

Sugimoto Y., Inazumi T., Tsuchiya S. (2015). Roles of prostaglandin receptors in female reproduction. J. Biochem., 157: 73-80.

S zy nd le r-Nędza M., R o p k a - M o lik K., P i órkow sk a K. (2016). Changes in body weight and fatness of sows during reproductive activity depending on $L E P R$ and $M C 4 R$ genes polymorphism. Livest. Sci., 192: 25-32.

Szynd ler-Nędza M., R opka-Molik K., M u cha A., B li charski T., B abicz M. (2019). Performance traits of Pulawska pigs depending on polymorphism in the RYR1 gene (c.1843C $>$ T). Ann. Anim. Sci., 19: 319-326.

Terman A., K mi éc M., P olasik D., Rybarczyk A. (2011). Association between RBP4 gene polymorphism and reproductive traits in polish sows. J. Anim. Vet. Adv., 10: 2639-2641.

Traspov A., Deng W., Kostyunina O., Ji J., Shatokhin K., Lugovoy S., Zinovieva N., Yang B., Huang L. (2016). Population structure and genome characterization of local pig breeds in Russia, Belorussia, Kazakhstan and Ukraine. Genet. Sel. Evol., 48: 16.

Ty r a M., R ó ż y c k i M. (2004). Heritability of reproductive traits in pigs. Anim. Sci. Pap. Rep., 22: 235-242.

Van Rens B.T., Van der Lende T. (2002). Litter size and piglet traits of gilts with different prolactin receptor genotypes. Theriogenology, 57: 883-893.

Van e J.R., B a kh le Y.S., B ot ting R.M. (1998). Cyclooxygenases 1 and 2. Annu. Rev. Pharmacol. Toxicol., 38: 97-120.

Vin c ze T., P o s fa i J., R oberts R.J. (2003). NEBcutter: a program to cleave DNA with restriction enzymes. Nucleic Acids Res., 31: 3688-3691.

Wang S.J., L i u W.J., Yang L.G., S a rgent C.A., Li u H.B., Wang C., Li u X.D., Z ha o S.H., A ffar a N.A., L i a ng A.X., Z h a n g S.J. (2012). Effects of FUT1 gene mutation on resistance to infectious disease. Mol. Biol. Rep., 39: 2805-2810.

Wu F., Zhan W.G., S ong Q.Q., Li H.H., Xu M.S., Li u G.L., Z hang J.Z. (2019). Association analysis of polymorphisms of $\mathrm{G}$ protein-coupled receptor 54 gene exons with reproductive traits in Jiaxing Black sows. Asian-Australas J. Anim. Sci., 32: 1104-1111.

Zh a n g C.Y., Wang Z., B ru c e H.L., J a n z J., G od d a rd E., M o o r e S., P la s tow G.S. (2014). Associations between single nucleotide polymorphisms in 33 candidate genes and meat quality traits in commercial pigs. Anim. Genet., 45: 508-516.

Zhu S., Li u Y., Dong W., Zheng X., Zhu G., Wu S., B a o W. (2014). Polymorphism of FUT1 gene M307 and its relationship with partial immune indexes and economic traits in Yorkshire pigs. Asian J. Anim. Vet. Adv., 9: 255-261.

Received: 27 XI 2019

Accepted: 26 VI 2020 